\section{Association between Trauma to Primary Incisors and Crown Alterations in Permanent Successors}

Fernanda Cunha Soares ${ }^{1}$, Mariane Cardoso ${ }^{2}$, Michele Bolan²

\author{
'Department of Pediatric \\ Dentistry, Department of \\ Dentistry, UPE - University of \\ Pernambuco, Recife, PE, Brazil \\ ${ }^{2}$ Department of Pediatric Dentistry, \\ Department of Dentistry, UFSC \\ - Federal University of Santa \\ Catarina, Florianópolis, SC, Brazil
}

Correspondence: Dra. Fernanda Cunha Soares, Avenida Agamenon Magalhães, S/N, Bairro de Santo Amaro, 50100-010 Recife, PE, Brasil. Tel: +55-81-3183-3674.

\begin{abstract}
The aim of this study was to determine the prevalence of sequelae in permanent teeth that had their predecessors traumatized and investigate associated factors. The study was carried out with clinical and radiographic data from 137 patient charts of the Traumatized Patient Care Program, Federal University of Santa Catarina (Brazil), totalizing 253 teeth. Data were gathered on gender, age at the time of trauma, type of trauma, type of posttrauma sequelae, trauma recurrence and crown alteration in the permanent successors. No statistically significant associations were found between permanent successor's crown alteration and gender, age at the time of trauma, post-trauma sequelae or trauma recurrence $(p>0.05)$. Significant associations were found between severe trauma (crown fracture with pulp exposure, lateral luxation, intrusion and extrusion) in the primary incisors and permanent successor's crown alteration $(p<0.05)$. Multivariate analysis revealed an association between severe trauma to the primary incisors and permanent successor's crown alteration (OR: 4.1 - IC: 1.7-10.1). Alterations in the crown of permanent successors are associated with severe trauma to the primary incisors, as primary teeth affected by severe trauma have a fourfold greater chance of exhibiting permanent successor crown alteration in comparison to primary teeth that had minor trauma.
\end{abstract}

\section{email: fercsoares@gmail.com}

Key Words: dental trauma, primary teeth, dental fractures.

\section{Introduction}

Dental trauma is currently considered a public health problem, especially where the rate of dental caries has undergone considerable decrease in recent decades $(1,2)$. In cases of alveolar-dental trauma to the primary dentition, the 1-4-year-old age group is the most affected. In this development phase, children are learning to walk and developing motor skills $(3,4)$.

Besides the epidemiological relevance, it is essential to understand the consequences that may stem from dental trauma - the sequelae that occur in the primary teeth as well as the corresponding permanent successors (5). The prevalence of development disorders in permanent successors caused by trauma to the corresponding primary teeth ranges from $12 \%$ to $74 \%$, partially due to the close relationship between the apex of the primary tooth and development of the permanent successor $(4,6)$. The severity of the sequelae depends on the child's age at the time of injury, the amount of root resorption of the traumatized tooth, the type and extent of the injury and the successor's development phase at the time of injury. The types of trauma that most affect the permanent successors are intrusion and avulsion of the primary tooth (4-8).

Sequelae in the permanent tooth stemming from trauma to the primary dentition can affect the crown, root or the entire permanent successor. Sequelae that affect the crown are structural alterations associated with hypoplasia of the enamel, dilaceration of the crown and yellow or brown coloration (9). Sequelae that affect the roots include duplication and partial or total dilaceration. When the entire bud of the permanent successor is affected, there may be alterations in the eruption process, retention or malformation of the permanent tooth (9).

Considering the prevalence of dental trauma in children, the aim of the present study was to determine the prevalence of sequelae in permanent teeth that had their predecessor traumatized and associated factors (gender, age, type of trauma, type of sequel in primary teeth and recurrence of trauma), in Florianópolis, SC, Brazil.

\section{Material and Methods}

A descriptive, retrospective study was carried out involving the analysis of patient charts of children treated at the Traumatized Patient Care Program (primary teeth) of the Trauma Clinic of the Pediatric Dentistry Department, Federal University of Santa Catarina (Brazil), between August 1998 and December 2010.

The charts were analyzed based on the inclusion criterion of trauma to primary maxillary incisors. The exclusion criteria were lack of follow up through the eruption of the permanent successor, primary teeth with caries and/or restorations, and charts with incomplete data. Thus, 137 patient charts fulfilled the eligibility criteria, totaling 253 traumatized primary teeth. 
This study made a census of the charts available at the Trauma Clinic of the Pediatric Dentistry Department and because of that no calculation of sample size was made $a$ priori. Based on the results of this paper (OR: 4.1; Cl 95\%; prevalence of 'disease' in unexposed group of 3.7\%) the required sample size was 330 teeth, but only 253 teeth were available for analysis.

The following data were collected: gender; injured tooth; type of trauma categorized into: a) minor: fracture without pulp exposure, concussion and subluxation; b) severe: fracture with pulp exposure, lateral luxation, intrusion and extrusion; age of the child at the time of trauma ( $<48$ months and $\geq 48$ months); type of posttrauma sequelae categorized into: a) minor: mobility, crown discoloration and obliteration; b) severe: pulp necrosis; trauma recurrence (present or absent), and effects on the crown of the permanent successor (present or absent).

The data were entered in Microsoft Excel and analyzed using the SPSS program, version 17.0 (SPSS Inc., Chicago, IL, USA). The chi-square test was employed to assess associations between crown alterations in the permanent successors of traumatized primary maxillary incisors and

Table 1. Description and simple frequency of the studied variables

\begin{tabular}{lcc}
\hline Variable & $\mathrm{n}^{*}$ & $\%$ \\
\hline Gender & & \\
Male & 50 & 58.3 \\
Female & 41.6 \\
Age & 204 & 80.6 \\
<48 months & 49 & 19.4 \\
$\geq 48$ months & & \\
Type of trauma & 195 & 77.1 \\
Minor & 58 & 22.9 \\
Severe & & \\
Type of post-trauma sequelae in primary teeth & 78 & 30.84 \\
No sequelae & 119 & 47.03 \\
Minor & 56 & 22.13 \\
Severe & & \\
Trauma recurrence & 233 & 92.1 \\
Absent & & 7.9 \\
Present & 210 & 83.0 \\
Permanent successor crown alteration & & 17.0 \\
Absent & & \\
\hline & & \\
\hline
\end{tabular}

*Number of valid observations. the other variables. Univariate logistic regression analysis was performed to estimate the effect of the independent variables on the outcome. The level of significance was set to $5 \%(p<0.05)$.

\section{Results}

The prevalence of sequelae in permanent teeth due to trauma in the primary tooth was $7.9 \%$. Table 1 displays the characterization of the sample. Table 2 presents the types of sequelae in the traumatized teeth. Table 3 presents the types of trauma in primary teeth.

Among the alterations in the permanent successor crowns, hypoplasia was found in 10 teeth (50.0\%), alterations in the shape of the permanent successor and the presence of white spot lesions were found in 4 teeth $(20.0 \%)$ and yellow spots were found in 2 teeth (10.0\%).

A statistically significant association $(p<0.05)$ was found between crown alterations in the permanent successor and type of trauma. No statistically significant association was found between crown alterations in the permanent successor and gender, age, type of post-trauma sequelae in primary tooth and trauma recurrence (Table 4).

Table 2. Type of post-trauma sequelae in the primary teeth

\begin{tabular}{lc}
\hline Type of sequelae & $\%$ \\
\hline Minor sequelae & \\
Mobility & 58.00 \\
Color alteration & 23.50 \\
Obliteration & 18.50 \\
Severe sequelae & \\
Pathologic resorption & 75.00 \\
$\quad$ Periapical lesion & 25.00 \\
\hline
\end{tabular}

Table 3. Type of trauma in the primary teeth

\begin{tabular}{lc}
\hline Type of trauma & $\%$ \\
\hline Minor trauma & 6.66 \\
Enamel fracture & 8.20 \\
Enamel and dentin fracture with pulp exposure & 25.64 \\
Concussion & 59.48 \\
Subluxation & \\
& \\
Severe trauma & 20.68 \\
Enamel and dentin fracture without out pulp exposure & 34.48 \\
Lateral luxation & 44.82 \\
\hline
\end{tabular}


Permanent teeth with sequelae had different types of trauma: subluxation $-40.0 \%$, intrusion $-30.0 \%$, enamel and dentin fracture with pulp exposure $-25.0 \%$, and lateral luxation - 5.0\%. Among the permanent teeth without esthetic alterations, $45.5 \%$ were cases of subluxation, $20.6 \%$ were cases of concussion, $8.6 \%$ were cases of lateral luxation, $8.6 \%$ were cases of intrusion, $6.9 \%$ were cases of enamel and dentin fracture without pulp exposure, 5.6\% were cases of enamel fracture and $4.3 \%$ were cases of enamel and dentin fracture with pulp exposure.

Based on the results of the chi-square test (Table 4), the type of trauma $(p<0.05)$ was included in the univariate logistic regression. Primary teeth affected by severe trauma had a fourfold greater chance of exhibiting esthetic alterations in the permanent successors in comparison to those that suffered minor trauma (Table 5).

\section{Discussion}

The sequelae prevalence in permanent teeth by trauma in primary tooth was $7.9 \%$, a lower prevalence comparing with other studies performed in Brazil (11.9\%) (10). The highest prevalence of trauma was subluxation (45.85\%). The most prevalent sequela in primary teeth after trauma was dental mobility (39.43\%), and the most prevalent sequela in permanent teeth was hypoplasia (50.0\%). There

Table 4. Association between traumatized primary teeth with and without alteration in the crown of the permanent successor and variables

\begin{tabular}{|c|c|c|c|c|c|c|}
\hline \multirow{2}{*}{ Variable } & \multicolumn{2}{|c|}{$\begin{array}{l}\text { No crown } \\
\text { alteration }\end{array}$} & \multicolumn{2}{|c|}{$\begin{array}{l}\text { Crown } \\
\text { alteration }\end{array}$} & \multirow{2}{*}{$\chi^{2}$} & \multirow{2}{*}{$\mathrm{p}$} \\
\hline & $\mathrm{n}$ & $\%$ & $\mathrm{n}$ & $\%$ & & \\
\hline Gender* & & & & & 0.135 & 0.713 \\
\hline Male $(\mathrm{n}=80)$ & 73 & 53.3 & 7 & 5.1 & & \\
\hline Female $(n=57)$ & 53 & 38.7 & 4 & 2.9 & & \\
\hline Age & & & & & 1.220 & 0.269 \\
\hline$<48$ months & 186 & 73.5 & 18 & 7.1 & & \\
\hline$\geq 48$ months & 47 & 18.6 & 2 & 0.8 & & \\
\hline Type of trauma & & & & & 12.531 & $<0.001^{*}$ \\
\hline Minor & 178 & 70.4 & 8 & 3.2 & & \\
\hline Severe & 55 & 21.7 & 12 & 4.7 & & \\
\hline \multicolumn{5}{|c|}{ Post-trauma sequelae in primary teeth } & 3.583 & 0.058 \\
\hline Minor & 183 & 72.3 & 12 & 4.7 & & \\
\hline Severe & 50 & 19.8 & 8 & 3.2 & & \\
\hline Trauma recurrence & & & & & 0.139 & 0.709 \\
\hline Present & 39 & 15.4 & 4 & 1.6 & & \\
\hline Absent & 194 & 76.7 & 16 & 6.3 & & \\
\hline
\end{tabular}

${ }^{*} \mathrm{n}=137$ patients. were statistical associations between permanent teeth sequelae and trauma, in which primary teeth affected by severe trauma had 4 times more chance to present esthetic alterations in the permanent successor compared with teeth affected by minor traumas. There were no associations of permanent teeth sequelae with gender, age, type of sequelae in primary teeth and recurrence of trauma in primary teeth.

This is an ecological study and the information obtained in the charts were filled out by an untrained dentist from the university dental clinic, using clinical and radiographic exams. Additionally, this dentist was not calibrated, which could cause information bias. Another limitation in this study is the fact that there might be an overestimation of the prevalence of trauma in primary tooth. The analyzed charts were from patients treated in the Traumatized Patient Care Program of the Trauma Clinic of the Pediatric Dentistry Department and probably the reported cases were the more severe traumas, since some parents do not take their children to treat minor traumas. Even so the study is valid, because sequelae in permanent teeth are more frequent after severe traumas.

The highest prevalence of subluxation is due to the small thickness and the density of the alveolar bone, therefore younger children are more likely to be affected by luxation than by fracture of the dental tissue, which corroborates the findings from previous studies (11-14). In this study, and in most studies in this field, the enamel hypoplasia is a common sequela in the permanent successors $(7,9,15)$. This is the major consequence of trauma in primary teeth of children aged 1 to 4 years, a period when the permanent successor crown is in the initial formation phase, Nolla's dental developmental stages 1-5 (16).

A statistically significant association was found between the type of trauma and crown alteration in the permanent successor, which corroborates the findings of previous studies reporting that severe trauma to the primary teeth constitute a risk to the formation of the permanent successors $(8,9)$. In the present study, children that suffered trauma such as lateral luxation, intrusion or extrusion had a fourfold greater chance of exhibiting a crown alteration in the permanent successor. These alterations ranged from whitish or brownish coloration to the loss of structure or

Table 5. Univariate logistic regression analysis for crown alteration in permanent successors

\begin{tabular}{lcc}
\hline Type of trauma & $\mathrm{OR}^{*}[95 \% \mathrm{Cl}]$ & $\mathrm{p}$ \\
\hline $0=$ Minor & 1.0 & \\
$1=$ Severe & $4.1[1.7-10.1]$ & $0.002^{*}$ \\
\hline
\end{tabular}

*Statistically significant if $\mathrm{p}<0.05$. 
a change in the shape of the crown.

It is important that parents be aware of the possible alterations in the permanent dentition and primary teeth after trauma and that the child should be periodically followed up by clinical and radiographic exams. With necrosis in primary teeth, the pediatric dentist is able to avoid the worst sequelae.

Whenever the diagnosis is made, before or after the permanent tooth eruption, the treatment can only be carried out after the complete eruption of the tooth. Currently, dentistry has esthetic treatment options that address the esthetic alterations in the crown.

In conclusion, alterations in the crown of permanent successors are associated with severe trauma to the primary incisors. Primary teeth affected by severe trauma have a fourfold greater chance of exhibiting esthetic crown alterations in permanent successors in comparison with primary teeth after a minor trauma.

\section{Resumo}

0 objetivo deste estudo foi determinar a prevalência de sequelas nos dentes permanentes, em crianças que tiveram o seu antecessor traumatizado e os fatores associados. 0 estudo foi realizado com dados clínicos e radiográficos de 173 prontuários de pacientes do Programa de Assistência ao Paciente Traumatizado, Universidade Federal de Santa Catarina (Brasil), totalizando 253 dentes. Os dados coletados foram: gênero, idade no momento do trauma, tipo de trauma, tipo de sequelas pós-trauma, recorrência de trauma e alteração na coroa dos sucessores permanentes. Não houve associação estatisticamente significativa entre alteração na coroa do sucessor permanente e gênero, idade no momento do trauma, sequela pós-trauma e recorrência de trauma $(p>0,05)$. Foram encontradas associações significativas entre trauma grave (fratura coronária com exposição pulpar, luxação lateral, intrusão e extrusão) nos incisivos decíduos e o sucessor permanente com alteração na coroa $(p<0,05)$. A análise multivariada revelou uma associação entre trauma grave nos incisivos deciduos e alteração no sucessor permanente (OR: 4.1- IC: 1,7$10,1)$. Alterações na coroa dos sucessores permanentes estão associadas com trauma grave nos incisivos deciduos. Dentes decíduos acometidos por trauma grave têm quatro vezes mais chance de apresentar alteração na coroa do permanente em comparação com trauma leve.

\section{Acknowledgements}

The authors acknowledge the financial support from the Brazilian Government Research Funding Agency CAPES (Coordenação de Aperfeiçoamento de Pessoal de Nivel Superior).

\section{References}

1. Andreasen J0, Andreasen FM. Textbook and Color Atlas of Traumatic Injuries to the Teeth. Oxford. Wiley-Blackwell, 2007: 912.

2. Lam $R$, Abbott $P$, Lloyd $C$, Lloyd $C$, Kruger $E_{1}$ Tennant M. Dental trauma in an Australian rural centre. Dent Traumatol 2008; 24:663-670.

3. Cunha RF, Pugliesi DM, de Mello Vieira AE. Oral trauma in Brazilian patients aged 0 - 3 years. Dent Traumatol 2001;17:210-212.

4. Vuletić M, Škaričić J, Batinjan G, Zdenko T, Bagić IC, Jurić H. A retrospective study on traumatic dental and soft-tissue injuries in preschool children in Zagreb, Croatia. Bosn J Basic Med Sci 2014;14:1215.

5. Holan G, Needleman HL. Premature loss of primary anterior teeth due to trauma - potential short- and long-term sequelae. Dental Traumatology 2014;30:100-106

6. Anthonappa RP, Ongtengco $\mathrm{KL}$, King NM. A report of an impacted primary maxillary central incisor tooth. Dent Traumatol 2013;29:420422.

7. Ranka M, Dhaliwal $H$, Albadri S, Brown C. Trauma to the primary dentition and its sequelae. Dent Update 2013;40:534-536,539-540,542

8. Sennhenn-Kirchner $S$, Jacobs HG. Traumatic injuries to the primary dentition and effects on the permanent successors - a clinical followup study. Dent Traumatol 2006;22:237-241.

9. Arenas $M$, Barberá $E$, Lucavechi $T$, Maroto $M$. Severe trauma in the primary dentition diagnosis and treatment of sequelae in permanent dentition. Dental Traumatology 2006;22:226-230.

10. Jácomo DRES, de Carvalho VCQ, Campos V. Anterior deciduous teeth traumatisms: Retrospective longitudinal study during eight years. Arq Bras Odontol 2008;4:61-66.

11. Sanchez ALSF, Farinhas JA, Souza IPR. Primary dentition avulsion and intrusion - report case. Rev Bras Odontol 2002;59:54-56.

12. Kargul B, Çaglar E, Tanboga I. Dental trauma in Turkish children, Dent Traumatol 2003;19:72-75.

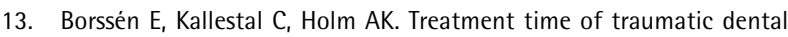
injuries in a cohort of 16-year-olds in northern Sweden. Acta Odontol Scand 2002;60:265-270.

14. Holan G, Ram D. Sequelae and prognosis of intruded primary incisors: a retrospective study. Pediatr Dent 2002;24:38-42.

15. Alexandre GC, Campos $\mathrm{V}$, Oliveira $\mathrm{BH}$. Intrusive luxation in primary dentition - two years follow-up. Rev Assoc Paul Cir Dent 2000;54:215219.

16. Nolla CM. The development of the permanent teeth. J Dent Child $1960 \cdot 27 \cdot 254-266$ 